\title{
Barnens inkomststandard under 90-talets djupa recession och den följande återhämtningen ${ }^{1}$
}

\author{
BJÖRN GUSTAFSSON, MATS JOHANSSON \\ \& EDWARD PALMER
}

\begin{abstract}
Vad har hänt med barnens inkomststandard under ett 90tal som i Sverige kännetecknas av först en kraftig arbetslöshetschock, nedskärningar i trygghetssystem och till sist återhämtning? Baserat på nya statistiska bearbetningar dras slutsatsen att nedgången i genomsnittlig inkomststandard var långvarig men inte unik för barnfamiljer.
\end{abstract}

\section{Inledning}

Ny jämförande forskning som redovisas i Vleminckx och Smeeding (2001) anger att Sverige har lyckats bättre eller till och med mycket bättre än de flesta andra OECD länder vad gäller barns ekonomiska välfärd och med att hålla fattigdom bland barn på en låg nivå. Högt arbetskraftsdeltagande bland föräldrarna, och då särskilt bland

Björn Gustafsson är professor i socialt arbete vid Göteborgs universitet.

Mats Johansson är fil doktor och forskare vid Institutet för framtidsstudier, Stockholm.

Edward Palmer är adjungerad professor i socialförsäkringsekonomi vid Uppsala universitet och chef för forskningsavdelningen vid Riksförsäkringsverket. mödrar, tillsammans med förhållandevis generösa transfereringar och omfattande offentlig barnomsorg är viktiga skäl för det goda utfallet.

Hur har detta varit möjligt? Är bilden entydigt positiv, eller finns det oroande inslag? Frågorna är berättigade eftersom Sverige i början av 90-talet drabbades av en djup recession. Mellan åren 1991 och 1993 exploderade den öppna arbetslösheten och

1 Uppsatsen bygger på forskning som finansierats av Socialvetenskapliga Forskningsrådet (SFR, numera Forskningsrådet för arbetsliv och socialvetenskap, FAS) och Riksförsäkringsverket. Vi tackar Kjell Jansson och Bengt Olof Gert vid Statistiska Centralbyrån för råd respektive tabelluttag från databasen. 
därefter skars de offentliga utgifterna ned. Vi ställer frågan: Hur påverkades barnens inkomststandard? Med hjälp av Statistiska Centralbyråns årliga undersökning av hushållens inkomster undersöker vi vad som hänt med barnens inkomststandard under 1990-talets djupa recession och den följande återhämtningen.

Delfrågor vi är intresserade av är: Hur förändrades barnens genomsnittliga inkomststandard och var förändringarna större eller mindre än för andra befolkningsgrupper? Hur påverkades barn i olika delar av fördelningen av inkomststandard? Hur påverkades ensamföräldrar och deras barn? I vilken utsträckning motverkade transfereringar och inkomstskatter de olikhetsgenererande krafter som kom från arbetsmarknaden?

Uppsatsen är disponerad på följande sätt: I nästa avsnitt tecknar vi en bakgrund om förändringar på arbetsmarknad och i socialpolitik under 90-talet. Avsnitt 3 beskriver hur vi mäter inkomststandard bland barn. Resultat som visar hur inkomststandarden förändrats redovisas $i$ avsnitt 4. Inkomststandardens utveckling bland ensamföräldrar och deras barn redovisas i avsnitt 5, medan avsnitt 6 handlar om fattigdom bland barn. En analys av skäl till att olikheten i inkomststandard förblev relativt oförändrad görs i avsnitt 7 och till slut summeras resultaten $i$ avsnitt 8 .

\section{Förändringar på arbetsmarkanden och $\mathrm{i}$ socialpolitik under 90 -talet.}

Världsekonomins nedgång i början av 90talet påverkade Sverige kraftigare än de flesta andra OECD-länder. Den bubbla som byggts upp av krediter och fastighetspriser sprack och den svenska ekonomin mötte en kraftigt minskad efterfrågan av såväl externa som interna skäl. Från en situation på arbetsmarknaden med 2 procents öppen arbetslöshet och 2 procent av arbetskraften i arbetsmarknadspolitiska åtgärder år 1989 ökade summan av andelen öppet arbetslösa och personer i åtgärder till hela 14 procent år 1993. BNP föll med 5 procent från 1990 till år 1994, och Sverige gick snabbt in i sin djupaste lågkonjunktur på många decennier.

Den stora ökningen av det relativa arbetslöshetstalet är bara en del av vad som hände på arbetsmarknaden. En annan, och även den mycket viktig förändring var att arbetskraften krympte. Medan 84,5 procent av befolkningen i åldern 16 - 64 fanns i arbetskraften vid slutet av 80-talet, hade arbetskraftsdeltagande sjunkit till bara 78,2 procent år 1995.

Även om den djupa nedgången påverkade alla befolkningsgrupper, fanns det stora skillnader. (Gustafsson \& Palmer 2002) Till exempel fanns det ett mycket klart åldersmönster. Nytillträdande till arbetsmarknaden mötte stora problem att hitta ett första arbete. Ungdomsarbetslösheten blev mycket hög för svenska förhållanden och sysselsättningen bland unga föll mycket snabbt. Däremot var påverkan mycket mindre bland de medelålders och de äldre. Äldre löntagare skyddades av turordningsregler och blev inte arbetslösa i samma utsträckning som yngre personer.

De inkomstmässiga konsekvenserna av recessionen varierade mellan personer av olika åldrar. Medan medelålders personer som förlorade sysselsättning var berät- 
tigade till arbetslöshetsersättning, stod unga vuxna utan tillräckliga arbetsmarknadshistorier utan ersättning från arbetslöshetskassorna. Föga förvånande ökade socialbidragstagandet snabbast bland de unga vuxna.

Offentliga utgifter ökade eftersom kostnaderna för arbetslöshetsersättning exploderade medan skatteinkomsterna sjönk fram till mitten av 90-talet. Som en konsekvens ökade det offentliga budgetunderskottet mycket snabbt. Många offentliga utgiftssystem utsattes för nedskärningar och en särskild värnskatt infördes på högre inkomster. Dessutom återinfördes egenavgifter för socialförsäkringar stegvis så att de uppgick till 6,95 procent år 1998.

Låt oss se något mer i detalj på förändringar i stöden till barnfamiljerna under den period vi studerar här. Barnbidragen höjdes först 1990 till 560 kronor per barn och månad och året därpå till 750 kronor per månad. Flerbarnstilläggen förstärktes också. I reala termer nådde barnbidraget då sin högsta nivå någonsin. År 1995 justerades flerbarnstilläggen ned, och år 1996 blev barnbidraget föremål för en nominell sänkning för första gången sedan de infördes. Flerbarnatillägget började fasas ut $\mathrm{i}$ januari 1996. Men ändringar därefter har varit i motsatt riktning. Barnbidraget var i januari 1998 tillbaka till 750 kronor och barn och flerbarnstilläggen återställdes.

Andra förändringar gällde stödet för ensamföräldrar och deras barn. Bidragsförskottssystemet ersattes med underhållsstöd bland annat i syfte att få underhållsskyldiga föräldrar att betala mer. Reglerna i bostadsbidraget gjordes om år 1996 vilket medförde att antalet berättigade barn- familjer minskade, ca 25 procent bland tvåförälderfamiljer och ca 20 procent bland ensamförälderfamiljer. Därtill sänktes ersättningsnivåerna i föräldraförsäkringen och i sjukersättningssystemet. Medan förändringarna $i$ transfereringssystemen alla var i riktning mot lägre eller indragna ersättningar var bilden delvis annorlunda för barnomsorgen. Antalet platser i barnomsorgen ökade, men till bilden hör även att de genomsnittliga resurserna per plats minskade högst betydligt.

BNP började åter att öka vid 90-talets mitt och arbetslösheten började sjunka, dock till en början enbart mycket långsamt. Siffror från OECD om hur BNP förändrats i dess medlemsländer åren 1990 - 1998 placerar Sverige nära botten. Lägre tillväxt noterades enbart för Schweiz, Ungern och Tjeckien. Den svenska tillväxten under perioden var bara hälften så stor som i Australien, Kanada, Storbritannien och Spanien, den var bara en tredjedel av tillväxten i USA.

När Sverige gick in i det nya millenniet var ekonomin tillbaka på en bana med BNP tillväxt, faktiskt högre än i många andra OECD länder. Arbetslösheten hade blivit så låg att det fanns arbetskraftsbrist i många sektorer, särskilt i storstäderna. Offentliga finanser var i gott tillstånd och politikens inriktning var att återställa trygghetssystemen till hur de var före nedskärningarna. Men när denna uppsats trycks är den makroekonomiska situationen mer oklar.

\section{Mått på barns inkomststandard}

Även om det länge gjorts välfärdsmätningar i Sverige, har barnen inte varit direkt syn- 
liga i dessa. Att låta barn vara respondenter är ett helt nytt och lovande angrepssätt, se SOU 2001:25. I denna artikel följer vi en kompletterande strategi som innebär att barn är redovisningsenhet vid beräkningar som utgår från hushållens disponibla inkomster. Sådant tillvägagångssättet har tillämpats vid flera forskningsansträngningar, men hittills inte för att belysa vad som hänt i Sverige under 1990-talet.

Data för denna studie kommer från Statistiska Centralbyråns undersökning av hushållens inkomster (HINK/HEK). Denna är en årlig urvalsundersökning som ofta består av ca 10000 hushåll och deras medlemmar. Undersökningen har genomförts sedan mitten av 1970-talet. Vår studie koncentreras på åren 1991 till och med 1998, men vi utnyttjar även information från tidigare år. Det finns dock ett metodproblem när det gäller jämförelser över tiden eftersom den stora skattereformen innebar att skattebasen breddades från och med år 1991. Definitionsförändringen innebar att hushållens observerade faktorinkomster ökades med i genomsnitt 5 procent. $^{2}$

När HINK ursprungligen designades bestämdes att ett hushåll kan bestå av upp till två vuxna och i förekommande fall barn. En person betraktas som ett barn fram till och med 18 års ålder. Detta är en begränsad definition som nyligen kommit att överges i den publicerade statistiken. Men eftersom vi vill göra jämförelser över hela 90-talet är vi tvungna att utnyttja

2 Det finns även andra skillnader i metod mellan åren, t e x har sampelstorleken förändrats. Dock är troligen dessa förändringar av mindre betydelse för resultaten. denna begränsade definition. All information om arbetsinkomster, skatter och om de allra flesta transfereringar hämtas från register, övrig information inhämtas genom telefonintervjuer.

Vår studie utgår från variabeln sinkomststandard». Denna erhålls genom att dividera ett hushålls disponibla inkomst med ett tal som uttrycker dess utgiftsbehov. Denna nämnare baseras på socialstyrelsens rekommendationer om socialbidragsnormer såsom de formulerades vid mitten av 1980-talet. ${ }^{3}$ Vi antar att konsumtionsmöjligheterna är jämnt fördelade i hushållet, vilket innebär att alla medlemmar delar jämt på hushållsinkomsten. Individer är analysenhet för studien, vilket innebär att ett hushållets tal för inkomststandard åsätts alla dess medlemmar. En egenskap med tillvägagångssättet är att värdet 1.0 motsvarar socialbidragsnormen (såsom denna formulerades vid 80-talets mitt).

På detta sätt kan vi ta fram värden för inkomststandard för alla barn i materialet, beräkna medelvärden för olika år, jämföra barns inkomststandard med inkomststandarden för andra personer och analysera fördelningen av barnens inkomststandard. Tillvägagångssättet gör det även möjligt att studera inkomstfattigdom bland barn. Det är alltså möjligt att ta fram en detaljerad

3 Se Gustafsson (1987) för metoden. Denna innebär att bostadskostnaden behandlas separat, som ett belopp avhängingt antalet personer och region. Vi uppdaterar denna summa med resultat från SCBs årliga hyresundersökning. Övriga kostnader bestäms av antalet personer och för barn även av deras ålder. Denna post uppdateras med konsumentprisindex (exklusive posten för bostad). 
bild av hur barnens ekonomiska välfärd och fattigdom har utvecklats i Sverige under 1990-talet.

\section{Utvecklingen av inkomststandarden för barn}

I detta avsnitt beskriver vi hur inkomststandarden för barn har utvecklats. För jämförelse visar vi vad som hände under den tidigare nedgången av ekonomin. Sedan mitten av 70-talet har Sverige genomlevt två recessioner, den första åren 1978 till 1982, den senare åren 1991 till 1995. Under den förra steg arbetslösheten fram till och med år 1983; då sjönk (enligt beräkningar vi kunnat göra från materialet) den genom- snittliga inkomststandarden för barn med 3.8 procent. Denna minskning var marginellt lägre än minskningen för hela befolkningen. När ekonomin återhämtade sig steg den genomsnittliga inkomststandarden för barn varje år varigenom den år 1990 blev 20 procent högre än år 1983, vilket innebär 15 procent högre än år 1980. Inkomstutvecklingen för hela befolkningen var liknande.

Med denna bakgrund låt oss nu se på utvecklingen under 1990-talet enligt Figur 1 och Tabell la. Den genomsnittliga inkomststandarden bland barn sjönk från 1991 till år 1993 (då den öppna arbetslösheten nådde sitt maximum) med hela 9.7 procent. Därefter fortsatte nedgången, trots att arbetsmarknadssituationen för-

Tabell Ia.

Inkomststandard för barn 0-17 år, 1980 och 1991-1998. Kvot gentemot Socialstyrelsens vägledande socialbidragsnormer, inklusive schablon för bostadskostnader.

\begin{tabular}{llllllllllllll}
\hline & 1980 & 1991 & 1992 & 1993 & 1994 & 1995 & 1996 & 1997 & 1998 & & \multicolumn{3}{c}{ Procentuell förändring } \\
\hline Barn & $195 / 91$ & $98 / 95$ & $98 / 91$ & $98 / 80$ \\
Barn 0-7 år & 1,485 & 1,751 & 1,731 & 1,611 & 1,613 & 1,520 & 1,512 & 1,603 & 1,642 & $-13,2$ & 8,0 & $-6,2$ & 10,6 \\
Barn 8-17 år & 1,531 & 1,966 & 1,878 & 1,755 & 1,797 & 1,634 & 1,639 & 1,686 & 1,708 & $-16,9$ & 4,5 & $-13,1$ & 11,6 \\
Barn 0-17 år & 1,514 & 1,867 & 1,810 & 1,686 & 1,709 & 1,579 & 1,578 & 1,648 & 1,679 & $-15,4$ & 6,3 & $-10,1$ & 10,9 \\
Sverige & 1,682 & 2,043 & 1,994 & 1,867 & 1,925 & 1,773 & 1,794 & 1,858 & 1,858 & $-13,2$ & 4,8 & $-9,1$ & 10,5 \\
\hline
\end{tabular}

Skattereformen 1990-1991 breddade skattebasen med i genomsnitt ungefär 5 procent. Förändringen berörde främst inkomsttagare med höga inkomster.Av denna anledning är inkomstmåtten inte helt jämförbara före och efter skattereformen.

\section{Tabell Ib.}

Relativ inkomststandard för barn 0-17 år. 1980 och 1991-1998. Kvot gentemot Socialstyrelsens vägledande socialbidragsnormer, inklusive schablon för bostadskostnader

\begin{tabular}{|c|c|c|c|c|c|c|c|c|c|}
\hline & 1980 & |99| & 1992 & 1993 & 1994 & 1995 & 1996 & 1997 & 1998 \\
\hline \multicolumn{10}{|l|}{ Relativ inkomst för barn } \\
\hline jämfört med: & & & & & & & & & \\
\hline & 90,0 & 91,4 & 90,8 & 90,3 & 88,8 & 89,1 & 88,0 & 88,7 & 90,4 \\
\hline Ensamstående utan barn & 89,5 & 103,3 & 102,0 & 105,3 & 105,5 & 104,5 & 102,9 & 106,8 & 110,2 \\
\hline Par utan barn & 67,1 & 65,4 & 65,9 & 65,3 & 62,3 & 63,8 & 62,5 & 61,6 & 63,2 \\
\hline Pensionärshushåll & 103,5 & 105,6 & 99,9 & 96,7 & 91,5 & 91,3 & 88,9 & 92,7 & 95,4 \\
\hline
\end{tabular}

Gustafsson, Johansson \& Palmer: Barnens inkomststandard under 90-talets djupa recession ... 


\section{Figur I}

Inkomststandard för barn 0-17 år. 1980-1998.

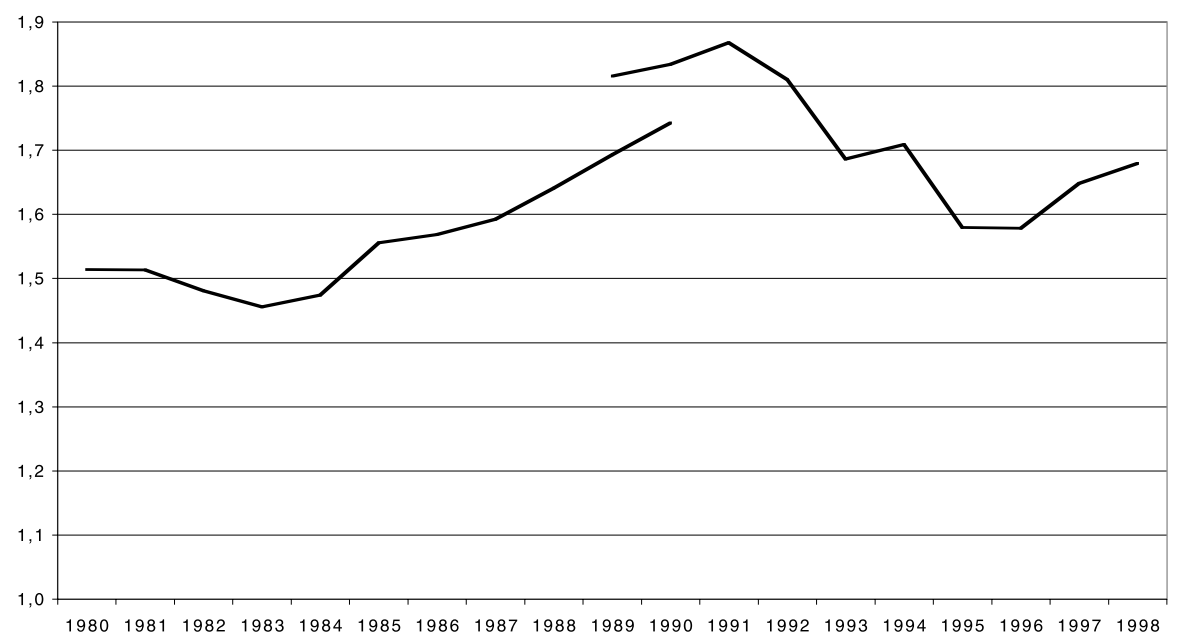

bättrades, och år 1996 var medelvärdet hela 14.2 procent lägre än år 1991. Sysselsättningskrisen hade den första och djupaste verkan på barnens genomsnittliga inkomststandard, men nedskärningarna $\mathrm{i}$ trygghetssystemen bidrog också.

Sedan år 1996 har barns genomsnittliga inkomststandard åter ökat. Ökningen mellan år 1996 och år 1998, då vår tidserie tar slut, är inte högre än 4.9 procent. Det innebär att värdet år 1998 var 10 procent lägre än det för år $1991 .^{4}$

Våra data visar att det finns befolkningsgrupper för vilka utvecklingen av

4 Oxley $\mathrm{m}$ fl (2001) raporterar att inkomststandarden för barn i Sverige ökade (i reala termer) med 7.8 procent mellan år 1983 och 1995. Detta tal är likt vad som kan beräknas från enligt våra definitioner utifrån mikrodata (efter korrigering för definitionsförändringen). Alltså var minskningen i genomsnittlig inkomststandard under 1990-talet mindre än den tidigare ökningen från mitten av 80-talet. inkomststandarden var sämre än för barn, men också på motsatsen. Ensamstående utan barn i yrkesaktiv ålder förlorade mer än vad barn gjorde, något som speglar de stora svårigheterna för många unga att hitta ett arbete. Motsatsen är de äldre för vilka pensionernas köpkraft endast påverkades marginellt av det försämrade statsfinansiella läget.

Har utvecklingen slagit hårdare mot barn som lever under små omständigheter jämfört med sådana som har det gott ställt? Vi delar upp materialet efter inkomststandardens storlek i fem lika stora klasser, kvintilgrupper. Innan vi studerar de observerade talen gör vi ett tankeexperiment och ser hur hög barnens inkomststandard skulle ha varit i olika klasser under förutsättningen av att det fanns inga transfereringar från offentlig sektor och heller inga inkomstskatter, utan enbart faktorinkomster.

Tankeexperimentet gör det möjligt att undersöka i vilken utsträckning olikhets- 
skapande krafter kom från faktormarknaderna. Huvuddelen av faktorinkomsterna är löner. Men faktorinkomster inkluderar även räntor, utdelningar och realiserade kapitalvinster, t ex på aktier. Det är välkänt att många hushåll i Sverige drog nytta av aktiemarknadens uppgång under 1990talet, det handlar i stor utsträckning om personer med medelhöga eller höga arbetsinkomster.

\section{Figur 2a.}

Kvintilgruppvärden för faktorinkomst bland barn 0-7 år. Index 1991 = 100. 1991-1998.

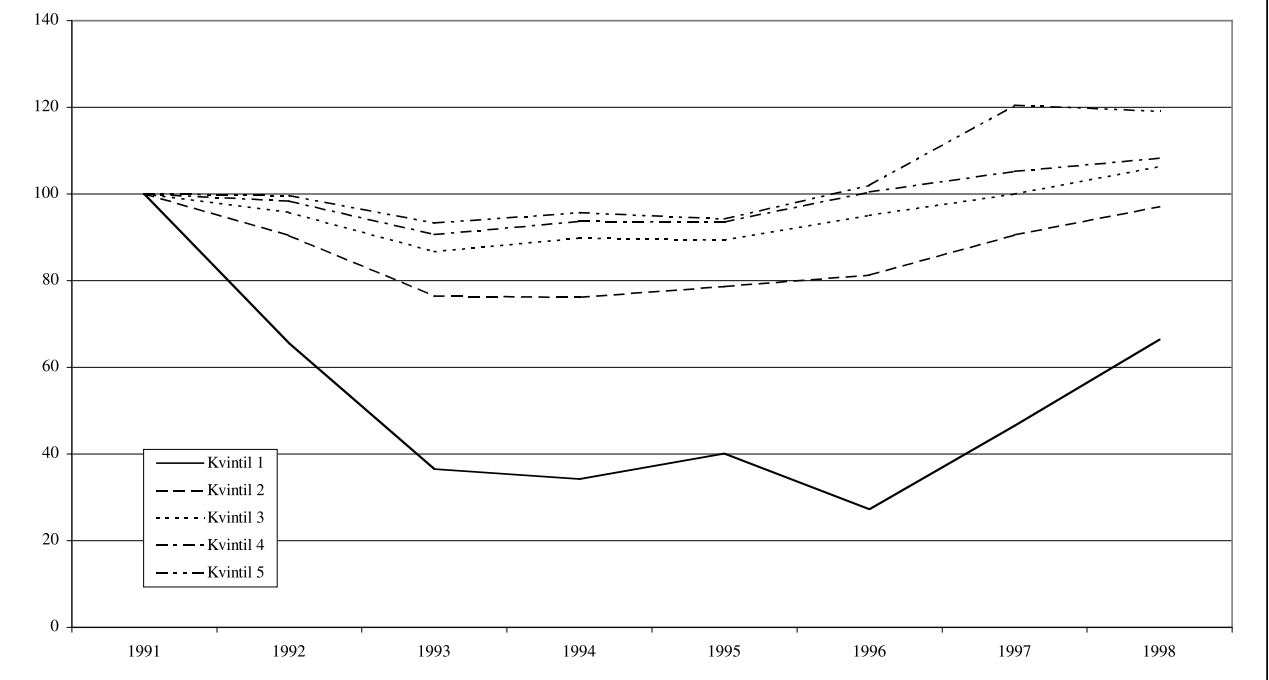

Figur 2b.

Kvintilgruppvärden för faktorinkomst bland barn 8-17 år. Index 1991 = 100. 1991-1998.

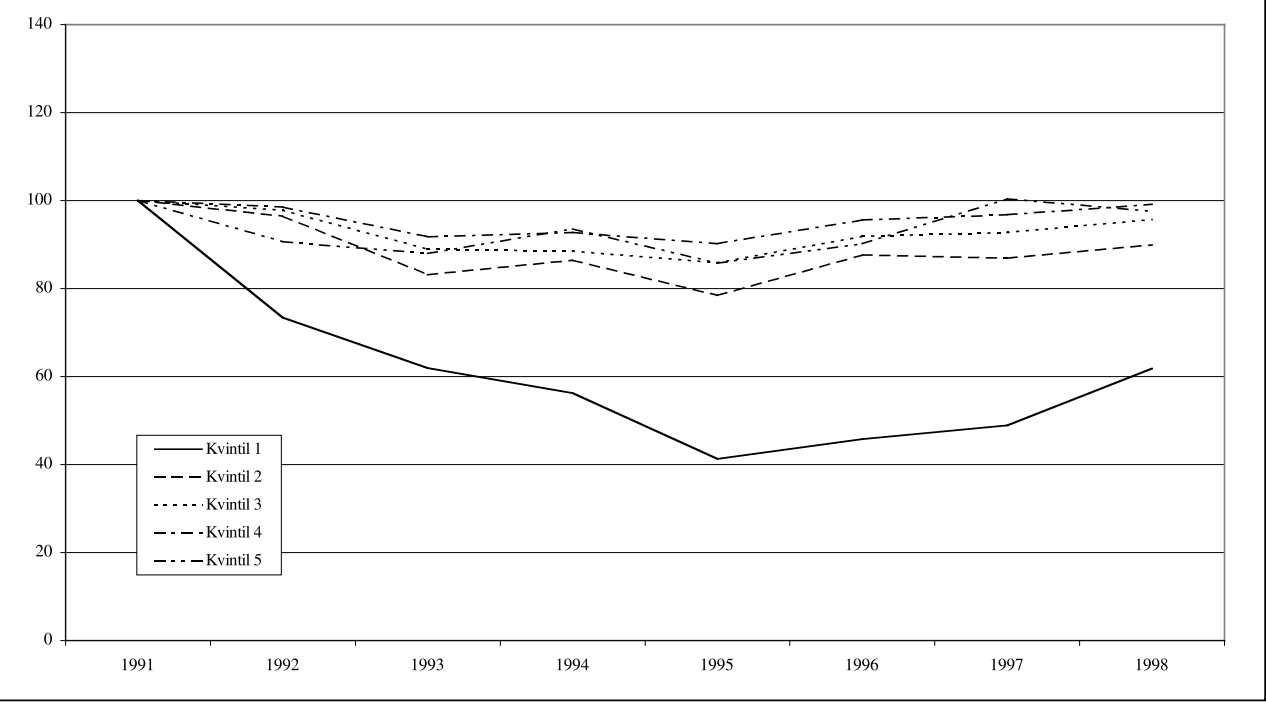

Gustafsson, Johansson \& Palmer: Barnens inkomststandard under 90-talets djupa recession ... 
Vi genomför analysen för barn i åldern 0 - 7 år respektive 8 - 17 år och utgår från faktorinkomsternas storlek. För varje kvintilgrupp sätter vi dess värde år 1991 lika med 100. Resultaten redovisas i Figur 2a och b som visar en mycket stor sänkning av faktorinkomsterna för dem med lägsta värden. Faktorinkomsterna för den första kvintilgruppen mer än halveras fram till mitten av 90-talet. Återhämtningen där-

\section{Figur 3a.}

Kvintilgruppvärden för inkomststandard bland barn0-7 år. Index 1991 = 100. 1991-1998.

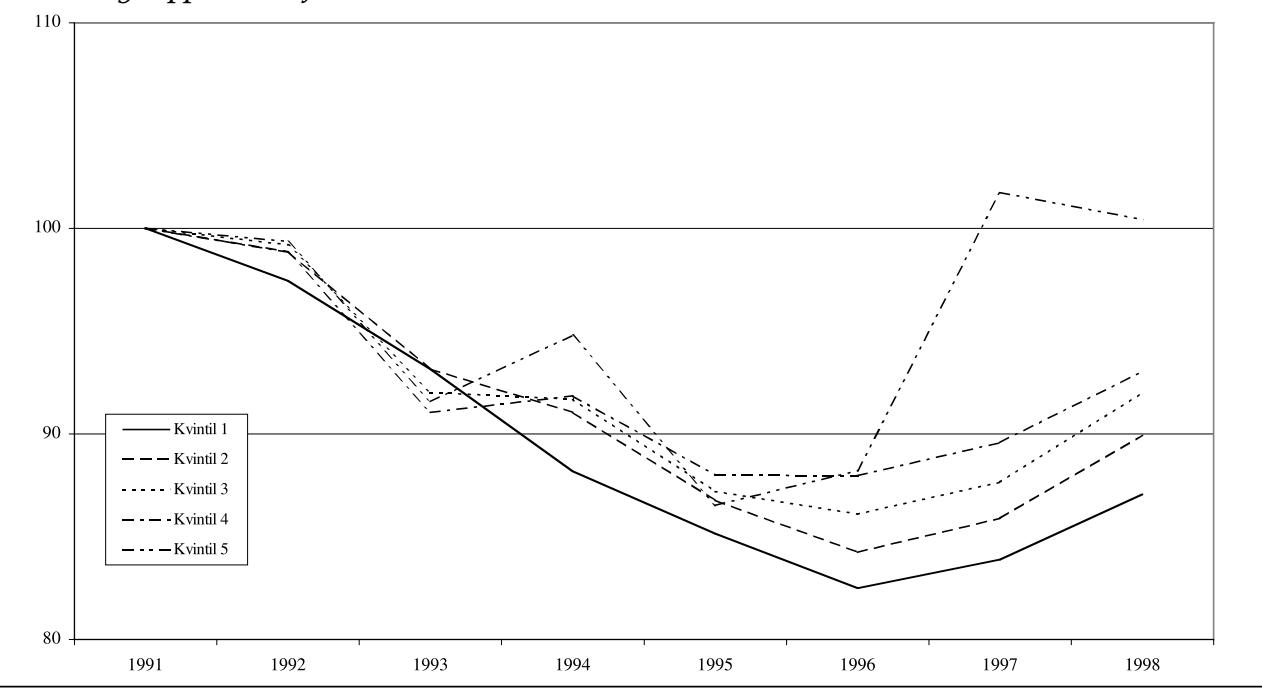

Figur 3b.

Kvintilgruppvärden för inkomststandardbland barn 8-17 år. Index 1991=100. 1991-1998.

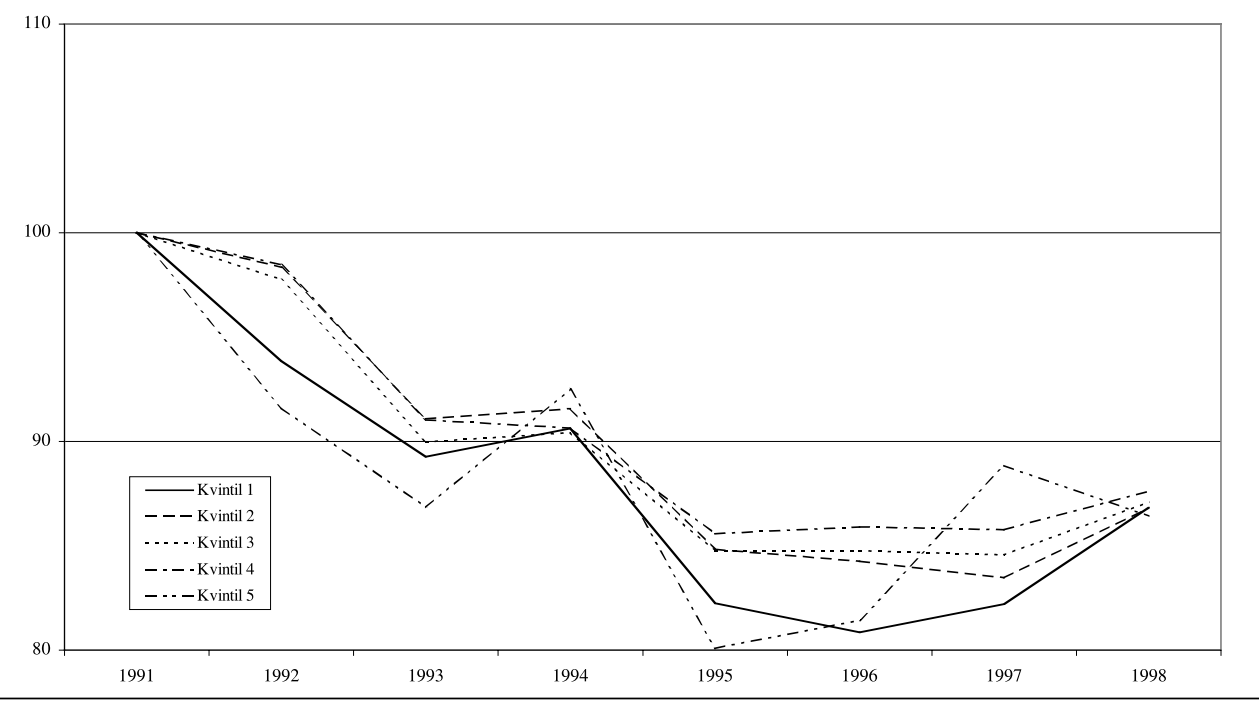

Socialvetenskaplig tidskrift nr $1 \cdot 2003$ 
efter är tydlig men mycket ofullständig. Vid slutet av perioden är nivån bara ca 60 procent av den för år 1991, det finns alltså fortfarande kvar ett stort gap.

Utvecklingen för övriga kvintilgrupper är inte alls lika dramatisk. Näst störst är sänkningarna för den andra kvintilgruppen som förlorade ca 20 procent av ursprungsvärdet. I de högre kvintilgrupperna har faktorinkomsterna vid periodens slut kommit tillbaka till 1991 års nivå, eller till och med överstigit denna.

Mot ovanstående bakgrund av mycket stora förluster av faktorinkomst i fördelningens lägsta del skall vi se på hur den verkliga inkomststandarden har utvecklats. Svaren ges i figur 3 som visar att det finns anmärkningsvärt liten skillnad i utvecklingen för de olika kvintilgrupperna. Det är enbart bland de yngsta barnen och vid periodens senare del som vi finner ett mönster som innebär en mer förmånlig utveckling för de i fördelningens topp. Tolkningen är att transfereringar från offentlig sektor skyddat inkomststandarden för barn i fördelningens botten från att falla kraftigare än för de högre upp i fördelningen.

Vår analys talar alltså för att välfärdsstaten i stor utsträckning lyckats motverka de olikhetsskapande processer som kommit från marknaden. För att formellt undersöka detta har vi beräknat numeriska värden på olikhetsindex. Resultat för det antagligen oftast använda indexet, Gini-koefficienten återges i Tabell 2. ${ }^{5}$ Där

5 Vi beräknade även andra olikhetsindex som tillhör den sk entropi-familjen (Thiels index och MLD-indexet). Resultaten om utveckligen över tiden var enligt dessa liknande.
Tabell 2.

Gini-koefficienten för inkomststandard för barn 0-7 år och 8-17 år gamla, 19911998.

\begin{tabular}{|c|c|c|}
\hline & $0-7$ år & $8-17$ år \\
\hline $199 \mid$ & 0,178 & 0,212 \\
1992 & 0,181 & 0,200 \\
1993 & 0,174 & 0,202 \\
1994 & 0,192 & 0,215 \\
1995 & 0,180 & 0,201 \\
1996 & 0,191 & 0,208 \\
1997 & 0,222 & 0,228 \\
1998 & 0,207 & 0,209 \\
\hline
\end{tabular}

ser vi att i enlighet med vad figur 3 anger finns det under andra hälften av 90-talet en trend mot ökande olikhet i inkomststandard för de yngsta barnen. Men det går inte att urskilja något motsvarande för barn i åldern 8 - 17 år.

Det är intressant notera att ur internationellt synvinkel är olikheten i inkomststandard bland barn i Sverige låg. Oxley $\mathrm{m}$ fl (2001) anger att Sverige tillsammans med Danmark har den lägsta olikheten i inkomststandard bland barn vid 1990talets mitt. Samma studie anger även att olikheten i inkomststandard bland barn i Sverige är liten även jämfört med den för hela befolkningen.

\section{Ensamföräldrar och deras barn}

Resultat av nyare jämförande studier anger att fattigdom bland ensamföräldrar och deras barn är ett betydligt mindre problem i Sverige än i de flesta andra jämförbara 
länder. Det är till och med så att enligt Bradbury och Jäntti (2001) har ensamförälderfamiljer i Sverige den allra lägsta fattigandelen bland de 25 länder studien omfattade. I en studie som jämför Italien, Storbritannien och Sverige visar Solera (2001) på att de flesta ensamföräldrar i Sverige är sysselsatta medan detta inte är fallet i Storbritannien och att detta är ett mycket viktigt skäl till att fattigandelen är lägre i Sverige. $\AA$ andra sidan är generösa transfereringar huvudskälet till att fattigdomen bland ensamföräldrar i Sverige är lägre än i Italien.

Medan ensamföräldrars situation i Sverige ter sig som fördelaktig ur ett internationellt jämförande perspektiv är detta emellertid inte hela bilden. På samma sätt som i Storbritannien har ensamma mödrar i Sverige en sämre hälsa. Whitehead $\mathrm{m} \mathrm{fl}$ (2000) rapporterar att skillnaden mellan ensamföräldrar och mödrar som lever i parförhållande är av samma storlek i båda länderna. Det är även känt att ensamföräldrar träffades hårdare än många andra grup- per av den ökande arbetslösheten under 1990-talets första del. T. ex visar Lundborg (2000) att omkring 10 procent av ensamföräldrarna var arbetslösa någon gång under år 1990, och detta gällde nästan en tredjedel år 1997. Detta kan jämföras med en ökning från kring 5 procent år 1990 för föräldrar i parförhållanden till omkring 10 procent år 1994. Nordmark (2000) finner att till viss del kan ensamföräldrarnas lägre sannolikhet att komma tillbaka till ett arbete när de väl blivit arbetslösa föras tillbaka på att de oftare är lågutbildade. En del i bilden av ensamföräldrars situation på arbetsmarknaden under 90-talet är att medan andelen heltidsarbetande ökat bland andra mödrar så har motsvarande inte varit fallet för ensamföräldrar (Gähler 2001).

Tabell 3 visar fördelningen av faktorinkomster bland personer i ensamförälderhushåll ( $\mathrm{d}$ v s barn såväl som föräldrar). Den första kvartilgruppen har så gott som ingen faktorinkomst, faktorinkomsterna är även så låga i kvintilgrupp 2 och 3 att dessa inte räcker till att föra hushållet över social-

\section{Tabell 3.}

Faktorinkomst för ensamföräldrar i kvintilgrupper, 1991-1998. Kvot gentemot Socialstyrelsens vägledande socialbidragsnormer, inklusive schablon för bostadskostnader.

\begin{tabular}{|l|c|c|c|c|c|}
\hline & Kvintil I & Kvintil 2 & Kvintil 3 & Kvintil 4 & Kvintil 5 \\
\hline 1991 & 0,037 & $0,49 \mid$ & 0,974 & 1,424 & 2,399 \\
1992 & 0,021 & 0,385 & 1,016 & 1,448 & 2,527 \\
1993 & $-0,026$ & 0,257 & 0,832 & 1,277 & 2,257 \\
1994 & $-0,005$ & 0,149 & 0,748 & 1,262 & 2,081 \\
1995 & 0,008 & 0,260 & 0,798 & 1,258 & 2,125 \\
1996 & $-0,004$ & 0,194 & 0,851 & 1,435 & 2,469 \\
1997 & $-0,003$ & 0,185 & 0,828 & 1,347 & 2,189 \\
1998 & 0,009 & 0,365 & 1,002 & 1,485 & 2,390 \\
\hline
\end{tabular}


bidragsnormen. Enbart kvintilgrupp 4 och 5 är självförsörjande i denna mening.

Eftersom den första kvintilgruppen hade så gott som ingen faktorinkomst kunde denna inte försämras under recessionen, men för den andra kvintilgruppen är förlusten dramatisk. Nivån hade halverats år 1993. Utvecklingen för andra kvintilgruppen var nedåtriktad ända fram till år 1997, varefter det verkar som en återhämtning påbörjats. Men ändå saknas år 1998 hela 26 procent för att den andra kvintilgruppens faktorinkomster skall komma tillbaka till storleken år 1991. Faktorinkomsterna för kvintilgrupp 3 - 5 sjönk mindre, och till skillnad från den för den andra kvinitilgruppen hade de återhämtat sig till fullo år 1998.

När vi ser hur den verkliga inkomststandarden för ensamföräldrar och deras barn utvecklats i tabell 4 är bilden mycket ljusare. För det första finner vi att medan enbart 4e och 5e kvintilgruppen kom över socialbidragsnormen med hjälp av egna förvärvsinkomster kommer med hjälp av transfereringar kvintilgrupp 2 och 3 klart över normen. Motsvarande gäller dock inte den första kvintilgruppen, som dock kommit upp till en nivå som är 85 eller 90 procent av normen. För det andra finner vi att medan den andra kvintilgruppen i fördelningen av faktorinkomster upplevde en mycket snabb försämring av sina resurser under recessionens första år, var fallet i disponibla inkomster begränsat ( $t$. ex 13 procent mellan åren 1993 och 1995). Även i de högre kvintilgrupperna dämpade transfereringar nedgången.

Den goda nyheten är alltså att inkomststandarden bland ensamföräldrar och deras barn inte påverkades mer negativt än för andra i yrkesverksamma åldrar under nedgången 1991 till 1995. Trygghetssystemen fungerade. Den dåliga nyheten är att ensamföräldrarna och deras barn inte deltagit i samma utsträckning som andra i den följande återhämtningen. Konsekvensen har blivit att en större andel av ensamföräldrar och deras barn för sin försörjning blivit beroende av transfereringar från offentlig sektor.

\section{Tabell 4.}

Inkomststandard för ensamföräldrar i kvintilgrupper, 1991-1998. Kvot gentemot Socialstyrelsens vägledande socialbidragsnormer, inklusive schablon för bostadskostnader.

\begin{tabular}{|l|c|c|c|c|c|}
\hline & Kvintil I & Kvintil 2 & Kvintil 3 & Kvintil 4 & Kvintil 5 \\
\hline 1991 & 0,933 & 1,310 & 1,450 & 1,604 & 2,153 \\
1992 & 1,026 & 1,326 & 1,484 & 1,655 & 2,315 \\
1993 & 0,897 & 1,230 & 1,374 & 1,520 & 2,019 \\
1994 & 0,832 & 1,158 & 1,331 & 1,500 & 1,974 \\
1995 & 0,832 & 1,121 & 1,274 & 1,419 & 1,895 \\
1996 & 0,845 & 1,116 & 1,275 & 1,430 & 1,991 \\
1997 & 0,835 & 1,106 & 1,252 & 1,404 & 1,777 \\
1998 & 0,904 & 1,146 & 1,291 & 1,433 & 1,863 \\
\hline
\end{tabular}

Gustafsson, Johansson \& Palmer: Barnens inkomststandard under 90-talets djupa recession ... 
Tabell 5.

Andel barn 0-17 år med inkomst under 50 procent av medianen. Beräkningar utifrån faktorinkomster respektive inkomststandard. 1980 och 1991-1998.

\begin{tabular}{|l|c|c|c|}
\hline & Faktor inkomst & Inkomststandard & $\begin{array}{c}\text { Skillnad: } \\
\text { Faktor inkomst } \\
\text {-lnkomststandard }\end{array}$ \\
\hline 1980 & 13,8 & 3,7 & 10,1 \\
1991 & 19,5 & 3,4 & 16,1 \\
1993 & 22,1 & 3,7 & 18,4 \\
1994 & 24,6 & 3,6 & 21,0 \\
1995 & 24,3 & 4,4 & 19,9 \\
1996 & 24,8 & 3,8 & 21,0 \\
1997 & 23,7 & 4,5 & 19,2 \\
1998 & 21,5 & 4,2 & 17,3 \\
\hline Skillnad 1995/199| & 20,8 & 4,2 & 16,6 \\
Skillnad 1998/1995 & 5,3 & 0,4 & \\
Skillnad 1998/199| & $-4,0$ & 0,4 & \\
Skillnad 1998/1980 & 1,3 & 0,8 & \\
\hline
\end{tabular}

\section{Fattigdom bland barn}

I detta avsnitt skall vi se närmare på barnfattigdom. Det finns inget officiell fattigdomsstreck för Sverige, och det finns två olika angreppssätt som har utnyttjats när det gäller att mäta inkomstfattigdom i vårt land. Vi kommer att använda båda. Det kommer visa sig att val av angreppssätt spelar stor roll för vilken bild av barnfattigdomens utveckling som visas.

Först finns det angreppssätt som är det vanligaste vid internationella jämförelser och enligt vilket fattigdomsstrecket sätts som någon andel av medianen eller medelvärdet av den fördelning som observeras. Ett val som gjorts i många jämförande studier är att sätta fattigdomsstrecket lika med 50 procent av medianen för inkomststandard. Detta är ett relativt mått som innebär att den allmänna inkomstnivån inte påverkar fattigdomsbedömningen. Det enda som är av betydelse är fördelningens utseende.

Vi observerade ovan enbart en svag tendens mot ökad olikhet i barns inkomststandard i Sverige under 1990-talet och medelvärdet för barns inkomststandard har förändrats ungefär som den för hela befolkningen. När vi använder ett relativt fattigdomsstreck bör vi alltså finna enbart en svag tendens till ökad barnfattigdom. Det är även vad Tabell 5 visar. T.ex. ökade andelen under fattigdomsstrecket från 3.4 procent år 1991 till 4.4 procent år 1994, 
och var 4.2 procent åren 1997-98. Alltså fortsatte Sverige att ha en låg andel barn under ett relativt fattigdomsstreck. ${ }^{6}$

Medan andelarna barn som faller under ett relativt fattigdomsstreck har ökat i några länder under 90-talet har så inte varit fallet i Sverige. Faktiskt är andelen barn under 50 procent av medianen år 1998 mycket lik den som observerades för år 1980. Men detta är inte hela historien. Det finns en långsiktig trend som består i att transfereringar blivit allt viktigare för att barn i Sverige skall undkomma fattigdom. Vi kan se detta i Tabell 5 genom att göra tankeexperimentet att sätta alla transfereringar och inkomstskatter lika med noll, och sedan beräkna hur många barn som under sådan förutsättning skulle vara fattiga ett givet år. Vi finner att det handlar om 14 procent år 1980. Av detta kan vi dra slutsatsen att transaktioner med offentlig sektor tagit 10 procent av barnen ur fattigdom. År 1991 handlar det om 16 procent av barnen och andelen ökade till 21 procent år 1993, året den öppna arbetslösheten kulminerade. Den fattigdomsreducerande effekten av offentliga transfereringar ökade alltså under recessionen, fram tills dess att återhämtningen kom i gång.

Under år med stora förändringar i genomsnittlig inkomst betyder det relativa angreppssättet till bestämning av ett fattigdomsstreck att dess köpkraft förändras. Under perioder av snabb tillväxt ökar även fattigdomsstrecket, och omvänt som i

6 Vår skattning för 1992 (3.7 procent) är identisk med den hos Bradbury \& Jäntti (2001), medan Oxley $\mathrm{m} \mathrm{fl} \mathrm{(2001)} \mathrm{rapporterar} \mathrm{för} \mathrm{år} 1995$ ett procenttal om 2.7 .
Sverige under recessionen under 90-talet. Av detta följer att resultat som visar att andelen barn som faller under ett relativt fattigdomsstreck är förhållandevis oförändrat behöver inte betyda annat än att barn i botten av fördelningen har upplevt samma förändring som andra personer i befolkningen. ${ }^{7}$ Därför kan det finnas goda skäl att tillämpa ett fattigdomsstreck som innebär en konstant köpkraft. Ett sådant angreppssätt används även när officiella skattningar av fattigdomen i USA görs. ${ }^{8}$ Utifrån ett sådant angreppssätt har vi baserat fattigdomsstrecket på rekommendationer som socialstyrelsen utfärdat för vägledande socialbidragsnormer såsom dessa formulerades vid 80 -talets mitt. ${ }^{9}$

Vi har sett att den genomsnittliga inkomststandarden för barn föll högst avsevärt under 1990-talet, och att det finns en viss tendens till ökad olikhet i barns

7 Se till exempel Noland (2001) som diskuterar hur barnfattigdom på Irland utvecklats genom att utnyttja detta angrepssätt.

8 Även detta angreppssätt har diskuterats. Ett viktigt argument gäller vad som händer när ekonomin tillväxer under en lång tid. Då riskerar ett fattigdomsstreck som står för en konstant köpkraft att bli socialt ointressant. Vid mitten av 90-talet diskuterade en kommitté vid National Academy olika frågor när det gäller att förändra den officiella definitionen. En rekommendation var att: »... omvärdera det officiella fattigdomsstrecket för USA för att ta hänsyn till såväl ett nytt resursbegrep som den konsumtionstillväxt som har skett sedan det officiella tröskelvärdet först bestämdes för 30 år sedan..."(Citro \& Michael 1995, s 106)

9 För mer detaljer se Gustafsson (2000). Angrepssättet har en halvofficiell status eftersom det tillämpats i all tre Sociala rapporter som Socialstyrelsen hittills publicerat. 
Tabell 6.

Andel barn 0-17 år med inkomst under 75, 100 och 125 procent av socialstyrelsens rekommendationer om socialbidragsnormen inklusive bostadskostnader. Beräkningar utifrän faktorinkomster respektive inkomststandard. 1980 och 1991-1998.

\begin{tabular}{|c|c|c|c|c|c|c|c|c|c|}
\hline & \multicolumn{3}{|c|}{ Faktor inkomst } & \multicolumn{3}{|c|}{ Inkomststandard } & \multicolumn{3}{|c|}{$\begin{array}{l}\text { Skillnad: Faktor inkomst } \\
\text {-Inkomststandard }\end{array}$} \\
\hline & $<0,75$ & $<1,00$ & $<1,25$ & $<0,75$ & $<1,00$ & $<1,25$ & $<0,75$ & $<1,00$ & $<1,25$ \\
\hline 1980 & 12,9 & 18,4 & 29,6 & 3,2 & 10,4 & 29,3 & 9,7 & 8,0 & 0,3 \\
\hline |99| & 15,0 & 20,9 & 28,9 & 1,5 & 4,7 & 12,8 & 13,5 & 16,2 & 16,1 \\
\hline 1992 & 17,1 & 23,5 & 31,7 & 1,9 & 5,1 & 13,4 & 15,2 & 18,4 & 18,3 \\
\hline 1993 & 21,1 & 28,3 & 38,0 & 2,2 & 6,7 & 18,6 & 18,9 & 21,6 & 19,4 \\
\hline 1994 & 21,6 & 27,8 & 36,4 & 2,8 & 7,6 & 20,2 & 18,8 & 20,2 & 16,2 \\
\hline 1995 & 22,2 & 29,6 & 37,4 & 2,6 & 8,3 & 24,5 & 19,6 & 21,3 & 12,9 \\
\hline 1996 & 21,6 & 26,5 & 33,9 & 2,6 & 9,6 & 27,1 & 19,0 & 16,9 & 6,8 \\
\hline 1997 & 19,6 & 25,5 & 32,5 & 2,7 & 9,9 & 26,2 & 16,9 & 15,6 & 6,3 \\
\hline 1998 & 18,1 & 24,6 & 30,9 & 2,4 & 8,6 & 23,0 & 15,7 & 16,0 & 7,9 \\
\hline Förändring |995/|99| & 7,2 & 8,7 & 8,5 & I,I & 3,6 & 11,7 & & & \\
\hline Förändring | 998/I 995 & $-4,1$ & $-5,0$ & $-6,5$ & $-0,2$ & 0,3 & $-1,5$ & & & \\
\hline Förändring |998/|99| & 3,1 & 3,7 & 2,0 & 0,9 & 3,9 & 10,2 & & & \\
\hline Förändring | 998/| 980 & 5,2 & 6,2 & 1,3 & $-0,8$ & $-1,8$ & $-6,3$ & & & \\
\hline
\end{tabular}

inkomststandard. Därför bör vi förvänta oss att allt fler barn faller under ett fattigdomsstreck som motsvarar en given köpkraft. Det är även vad vi finner i tabell 6. Medan 4.7 procent av barnen bedömdes om fattiga år 1991 hade andelen ökat årligen fram till 1997 då den var så hög som 9.9 procent. Barnfattigdom mätt på detta sätt fördubblades och nådde en nivå snarlik den 1980, vilket naturligtvis är en besvikelse. Det betyder att alla vinster i att minska barnfattigdomen under 1980-talet försvann under 1990-talet.

Det är även intressant att jämföra utvecklingen av barnfattigandelen definierad på detta sätt med vad som hände med barnfattigdomen i USA där uppdateringen av fattigdomsstrecket görs på samma sätt. Medan andelen fattiga barn i Sverige fördubblades från 1991 till 1997 föll motsvarande med en fjärdedel i USA mellan åren 1992 och $1999 .{ }^{10}$ Eftersom inkomstfördelningen i USA inte visade tendenser till att bli jämnare över tiden (snarare motsatsen) måste denna skillnad mellan länderna föras tillbaka på den avsevärt fördelaktigare utvecklingen av den allmänna inkomststandarden för barn i USA jämfört med den för barn i Sverige.

10 Se Freeman (2000). Lägg märke till att eftersom fattigdomsstrecken definierats på olika sätt kan de inte användas för jämförelser mellan länderna vid en given tidpunkt. 
Det finns mer information i Tabell 6 att kommentera. Först, skattningarna av andelen fattiga är känsliga för ganska små ändringar i fattigdomsstreckets nivå. Det finns många barn i familjer med disponibel inkomst som är bara marginellt högre än fattigdomsstrecket. Sänks fattigdomsstrecket med 25 procent resulterar det i en mycket låg andel fattiga barn, men om nivån höjs med 25 procent finner vi stora ökningar (såväl uttryckt som procentandelar som i procent). Medan 13 procent av barnen föll under 125 procent av fattigdomsstrecket år 1991 hade andelen ökat till så mycket som 27 procent år 1996. Under 90-talet ökade alltså andelen barn som levde under knappa förhållanden högst påtagligt.

Vi kan även göra samma tankeexperiment som för Tabell 5 genom att ersätta de observerade disponibla inkomsterna med faktorinkomster och se hur många barn som tas ut ur fattigdom och hur denna andel förändrats över tid. Åter finner vi att den fattigdomsminskande effekten var synnerligen stor vid 1990-talets början. Men när återhämtningen började blev den fattigdomsdämpande effekten mindre och faktorinkomsterna blev viktigare.

Mönstret för andelen barn vilka föll under 125 procent av fattigdomsstrecket är intressant, men även oroveckande. År 1993 skulle så många som 38 procent av barnen ha varit fattiga med 125 procents- definitionen. Men den observerade andelen var 18 procent, en skillnad om 20 procentenheter. År 1998 när ekonomin återhämtats var andelen barn under 125-procentsnivån beräknat utifrån faktorinkomster nere i 31 procent. Men, efter transfereringar och inkomstskatter, var den observerade ande- len ändå 23 procent, vilket faktiskt är högre än år 1993. 90-talets återhämtning syns alltså inte i dessa siffror. Varför? Ett skäl är att saneringen av statsfinanserna innebar ökad skattebelastning för barnfamiljerna, ett ämne som återkommer i nästa avsnitt.

\section{Varför förändrades olikheten i barnens inkomststandard enbart marginellt?}

Varför förändrades olikheten i barnens inkomststandard under den djupa recessionen enbart marginellt? Ramen för denna analys är något annorlunda än för den i föregående avsnitt eftersom vi genomför analysen för personer som lever i hushåll med referensperson i åldrarna 25 - 54 år. D v s vi analyserar den del av befolkningen där de flesta barn och deras föräldrar finns, och utelämnar äldre samt unga vuxna. Vi kommer att undersöka förändringar i fördelningen mätt med Gini-koefficienten.

Tabell 7 visar hushållens olika inkomstkällor för åren 1975, 1991 och 1998, deras nivå, relativa andelar av inkomststandarden och deras koncentrationskoefficienter samt varje inkomstkällas bidrag till Gini-koefficienten ett särskilt år. ${ }^{11}$ Koncentrationskoefficienten kan anta värden från - 1 som anger fullständig koncentration till dem med lägsta inkomststandard till +1 som står för fullständig koncentration till personer med högst inkomststandard. ${ }^{12}$

När vi börjar med att se på faktorinkomsterna finner vi att i genomsnitt är

11 Metoden bygger på Rao (1969) och Pyatt, Chen och Fei (1989).

12 För definition se t. ex Lambert (2001). 
Tabell 7.

Dekomponering av olikhet $i$ inkomststandard (IS) efter inkomstkälla i familjer med hushållsföreståndare 25-54 år. 1975, 1991 och 1998.

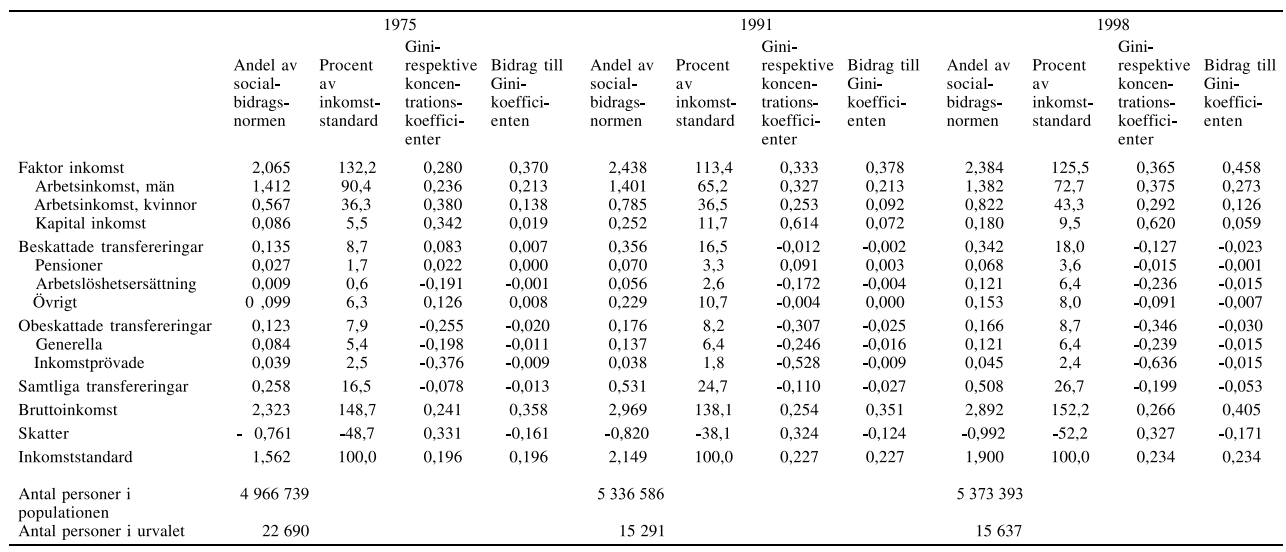

den största källan, föga förvånande, mäns arbetsinkomster, följda av kvinnors arbetsinkomster och minst är kapitalinkomsterna. De senare är mycket koncentrerade till dem med hög inkomststandard. ${ }^{13}$ Alla koncentrationskoefficienter är större än Gini-koefficienten. Med andra ord, är alla dessa komponenter olikhetsskapande. Men, för kvinnors arbetsinkomster är skillnaden mellan koncentrationskoefficienten och Gini-koefficienten liten åren 1991 och 1998 vilket antyder fördelningsmässig neutralitet.

Därefter ser vi på transfereringar och inkomstskatter. Vi skiljer mellan transfereringar som är skattepliktiga och andra transfereringar respektive inkomstskatter. Icke skattepliktiga transfereringar är antingen generella (t. ex. barnbidragen) eller inkomstprövade (t. ex. bostadsbi-

13 I de fall det inte fanns någon man / kvinna i hushållet har vi satt motsvarande inkomstkälla lika med noll. "Kapitalinkomster" inkluderar inkomst av eget hem, räntor, utdelningar och realisationsvinster. dragen och socialbidragen). Arbetslöshetsersättning är en viktig skattepliktig ersättning, och den utgjorde 0.6 procent av inkomststandarden år 1975 men hela 6.4 procent år 1998.

Koncentrationskoefficienterna för alla transfereringar är vid varje tidpunkt lägre än Gini- koefficienten, och flera är negativa. Det betyder att de är olikhetsminskande. Tabell 7 visar även att koncentrationskoefficienterna varierar avsevärt mellan de olika transfereringarna. Den största negativa koncentrationskoefficienten finns föga förvånande bland de behovsprövade icke skattepliktiga transfereringarna.

Till slut ser vi på inkomstskatterna och finner att deras koncentrationskoefficient är högre än för inkomststandarden. Det betyder att personer i fördelningens översta del betalar en procentuell andel av sin inkomst i skatt vilken är högre än motsvarande vid fördelningens lägre del. Inkomstskattesystemet är alltså progressivt.

Utifrån denna dekomponering kan vi fråga oss hur olika inkomstkällor bidragit 
till att hålla Gini-koefficienten förhållandevis stabil. Varje inkomstkälla kan påverka utvecklingen genom förändrad relativ andel och genom förändrad koncentrationskoefficient. Utvecklingen av Ginikoefficienten från 1991 till 1998 kan följas mellan varje par av år. Dekomponeringen ger oss numeriska värden för koncentrationskoefficienter och relativa andelar för varje komponent och år. Vi ställer samman informationen i Figur 4, som visar hur de tre komponenterna faktorinkomster har påverkat Gini-koefficienten för inkomststandard med år 1991 som basår, och Figur 5 som visar motsvarande information för olika transfereringar och inkomstskatter.

Enligt Figur 4 påverkade arbetsinkomster bland såväl kvinnor som män Gini-koefficienten uppåt och med ungefär samma styrka. Det går att utskilja en tillfällig uppbromsning år 1994 just då arbetslös- heten börjat sjunka, och förändringarna sedan 1996 är små. Jämför vi åren 1991 och 1998 finner vi att såväl mäns som kvinnors arbetsinkomster står för en större del av den genomsnittliga inkomststandarden det senare året, och vi finner även att koncentrationskoefficienterna har ökat.

Även kapitalinkomsternas utveckling har påverkat olikheten i inkomststandard. Denna komponent ligger bakom de "spikar" vi kan se i tidserien för åren 1994 och 1997 och de kan härledas till realisationsvinster. Men det finns mindre av trend i hur denna komponent påverkat olikheten mätt med Gini-koefficienten.

Vi ser nu på hur förändringar i transfereringar har påverakt Gini-koefficientens utveckling. Med undantag för pensionerna (förtidspension och änkepension) som hade en mer eller mindre neutral påverkan, bidrog alla till att motverka höjningen av

\section{Figur 4.}

Bidrag till förändring $i$ Gini-koefficienten bland familjer med hushällsföreståndare 2554 år sedan 1991, 1991-1998.

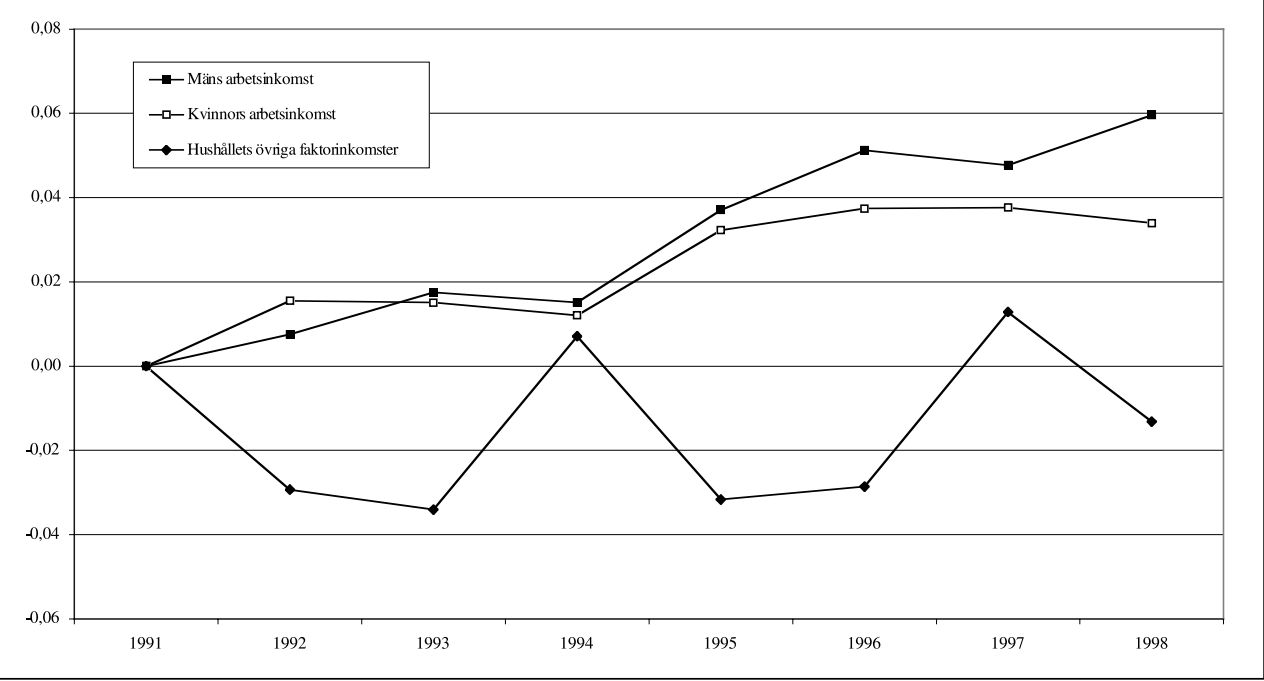

Gustafsson, Johansson \& Palmer: Barnens inkomststandard under 90-talets djupa recession ... 
olikheten. Arbetslöshetsersättning och andra transfereringar verkade båda i riktning mot minskad olikhet fram till mitten av 90-talet. Skattesystemets effekter kom senare, i den fas då statsbudgeten förstärktes. Figuren visar att från 1994 till 1997 verkade skattesystemet kraftigt mot minskad olikhet, en slutsats även dragen i Gustafsson \& Palmer (2002). Inkomstskattesystemets allt större olikhetsminskande effekt är resultatet av ett ökat skattetryck. Som kan beräknas från Tabell 7 betalade år 1998 personer i hushåll med föreståndare i åldern 25 - 54 år inkomstkatter och egenavgifter som var hela 21 procent högre än år 1991. Under samma tid föll deras inkomststandard med 12 procent.

\section{Slutkommentar}

Med hjälp av data från undersökningen av hushållens inkomster har vi analyserat vad som hänt med barns inkomststandard i Sverige under 1990-talet, en period under vars första del BNP sjönk, arbetslösheten exploderade men ekonomin därefter återhämtade sig. Vi kan dra flera slutsatser.

För de första. Vi har visat att nedgången i barnens inkomststandard under 1990talets djupa recession var mycket djupare och långvarig än motsvarande vid den föregående nedgången vid 1970-talets slut och 1980-talets början. Huvuddelen av nedgången ägde rum när arbetsmarkanden kraftigt försämrades. Denna avlöstes av en fas då förmåner i offentliga trygghetssystem minskades.

Det är anmärkningsvärt att trots återhämning sedan 1996 var barnens genomsnittliga inkomststandard år 1998 fortfarande 10 procent lägre än år 1991. Även om andelen barn som faller under ett relativt

\section{Figur 5.}

Bidrag till förändring $i$ Gini-koefficienten bland familjer medhushållsföreståndare 25-54 år sedan 1991, 1991-1998.

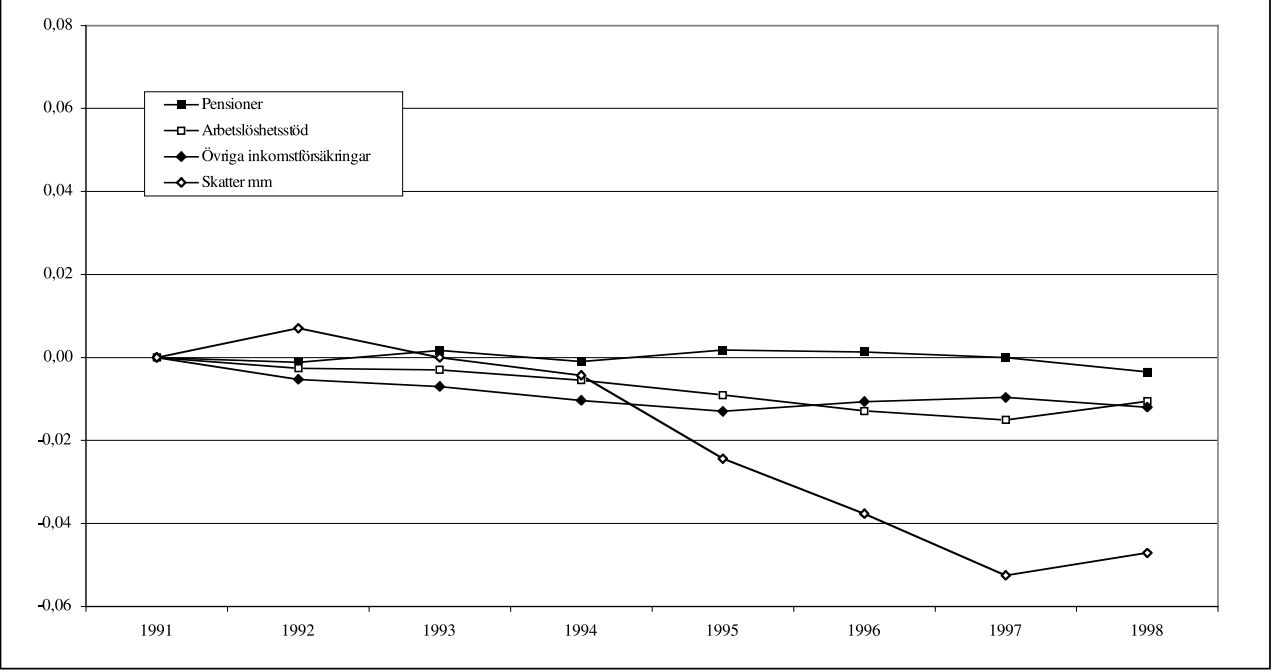


fattigdomsstreck år 1998 inte skiljer sig särskilt mycket från den år 1980 finns det en viktig skillnad. År 1998 var en avsevärt större andel barn och deras föräldrar beroende av offentliga transfereringar för att undkomma fattigdom. Arbetsinkomster spelade en större roll år 1980. I denna bemärkelse finns det en ökande marginalisering bland barn i Sverige.

För det andra. Nedgången under den studerade perioden var inte unik för barnfamiljer. De äldre var vinnare eftersom deras inkomster bara påverkades marginellt av recessionen. Bland hushåll i yrkesaktiva åldrar hittade vi vinnare och förlorare efter en annan dimension - nämligen arbetslivets insiders respektive outsiders.

Detta leder oss till den tredje slutsatsen. Bland barn fördelade efter inkomststandardens storlek påverkades den nedre delen av fördelningen kraftigt av minskade arbetsinkomster. Ökad avsaknad av förvärvsarbete var en stark kraft mot ökad olikhet i barns inkomststandard. Men i stor utsträckning motverkades denna utveckling av offentliga transfereringar, särskilt under processens första fas. Inte desto mindre finns det en tendens mot ökad olikhet i barns inkomststandard. Under återhämtningen betydde inkomstskatter mycket för att olikheten i barns inkomststandard inte skulle öka mer - genom att beskatta de bäst ställda.

En fjärde slutsats är att även om den ekonomiska situationen för ensamföräldrar och deras barn i Sverige fortsätter att vara god ur ett internationellt perspektiv, finns det orosmoln på himmelen. Arbetsmarknadssituationen för ensamföräldrar försämrades mer och under en längre period under 1990-talet än för andra föräldrar.

Regering och riksdag antog år 2001 målet att halvera socialbidragstagandet (mellan åren 2001 och 2004). En femte slutsats är att om Sverige skulle följa Storbritanniens exempel och sätta ett officiellt mål om att minska fattigdom bland barn kan det göra stor skillnad hur målet formuleras. Tilllämpas ett helt relativt angreppssätt när det gäller att definiera ett fattigdomsstreck får det som konsekvens att utvecklingen av barnfattigdomen under 1990-talet är långtifrån bekymmersam. Men detta skulle innebära att man bortser helt från faktumet att den genomsnittliga inkomststandarden föll.

Mätt mot ett fattigdomsstreck som står för samma köpkraft över decenniet ter sig situationen som bekymmersam. Detta mått på barnfattigdom nästan fördubblades under perioden, när under samma period och med samma sätt att uppdatera fattigdomsstrecket barnfattigdomen i USA minskade högst avsevärt. Av detta följer att vi ställer ut ekonomernas standardmedicin för fattigdomsbekämpning: ekonomisk tillväxt och ökat arbetskraftsdeltagande med offentliga transfereringar som nästbästa alternativ. 


\section{Litteratur}

Bradbury, B. \& Jäntti, M. (2001) "Child Poverty Across the Industrialised World: Evidence from the Luxembourg Income Study“ in Vleminckx, K. \& Smeeding, T. (Eds.) (2001) Child Well-Being, Child Poverty and Child Policies in Modern Nations, Bristol, Policy Press.

Citro, C. \& Michael, R. (1995) Measuring Poverty. A New Approach, Washington, D.C.: National Academy Press.

Freeman, R. (2000) "The Rising Tide Lifts...?" Focus, 21, (2), 27 - 31.

Gustafsson, B. (1987) Ett decennium av stagnerande realinkomster, Stockholm: Statistics Sweden Levnadsförhållanden Rapport 54.

Gustafsson, B. (2000) „Poverty in Sweden: Changes 1975 - 1995, Profile and Dynamicsu i Gustafsson, B. \& Pedersen, P. (Eds) Poverty and Low Income in the Nordic Countries, Aldershot: Ashgate.

Gustafsson, B. \& Palmer, E. (2002) "Was the Burden of the Deep Swedish Recession Equally Shared?", Review of Income and Wealth, 48, 537-560.

Gähler, M. (2001) "Bara en mor - ensamstående mödrars ekonomiska levnadsvilkor i 1990talets Sverige» i Bergmark, Å. (red) Ofärd i välfärden, Antologi Kommittén Välfärdsbokslutet / SOU 2001:54.

Lambert, P.J. (2001) The Distribution and Redistribution of Income, Tredje upplagan, Manchester: Manchester University Press.

Lundborg, P. (2000) "Nittiotalets förlorare", Arbetsmarknad \& Arbetsliv, 6, 235 - 248.

Nolan, B. (2001) "The Evolution of Child Poverty in Ireland", in Vleminckx, K. \& Smeeding, T. (Eds.) (2001) Child Well-Being, Child Poverty and Child Policies in Modern Nations, Bristol, Policy Press.

Nordenmark, M. (2000) „Familjesituation och arbetsmarknadsstatus. Vad förklarar ensamstående föräldrars låga sannolikhet att erhålla ett arbete?" Arbetsmarknad\& Arbetsliv, 6, 97 - 111.

Oxley, H., Dong, T - T, Förster, M., Pellizzasro, M (2001) "Income Inequalities and Poverty Among Children and Households With Children in Selected OECD Countries« i Vleminckx, K. \& Smeeding, T. (Eds.) (2001) Child Well-Being, Child Poverty and Child Policies in Modern Nations, Bristol, Policy Press.

Pyatt, G., Chan, C.N. and Fei, J. (1980) »The Distribution of Income by Factor Components", Quarterly Journal of Economics, 95, 451 - 473.

Rao, V.M. (1969) "The Decomposition of the Concentration Coefficient", Journal of Royal Statistical Society, 132, 418 - 425.

S. O. U 2001: 55 Barns och ungdomars välfärd, Forskarantologi från kommittén Välfärdsbokslut, Stockholm.

Solera, C (2001) »Income Transfers and Support for Mothers' Employment: The Link to Family Poverty Risks» in Vleminckx, K. \& Smeeding, T. (Eds.) (2001) Child Well-Being, Child Poverty and Child Policies in Modern Nations, Bristol, Policy Press.

Vleminckx, K. \& Smeeding, T. (Eds.) (2001) Child Well-Being, Child Poverty and Child Policies in Modern Nations, Bristol, Policy Press.

Whitehead, M., Burström, B \& Diderichsen, F (2000) "Social Policies and the Pathways to Inequalities in Health: A Comparative Analysis of Lone Mothers in Britain and Sweden", Social Science \& Medicine, 50, 255 - 270. 


\section{Summary}

\section{Child income in the deep recession of the 1990s and the subsequent recovery}

How has child income developed in Sweden during the 1990s, a period of unemployment shock, cuts in welfare systems, and subsequent recovery? Based on new statistics, we conclude that the downturn in average child income had a long duration, but was not unique to families with children.

During the initial phase, joblessness forcefully contributed to increased inequality in child income, although this was counterbalanced by public transfers. The labour market situation of single parents deteriorated more than that of other parents. When the recovery began, income taxes contributes to keeping inequity in child income low. It is concluded that if Sweden were to adopt an official goal of reducing child poverty it could make a great difference to how the goal was to be formulated. 